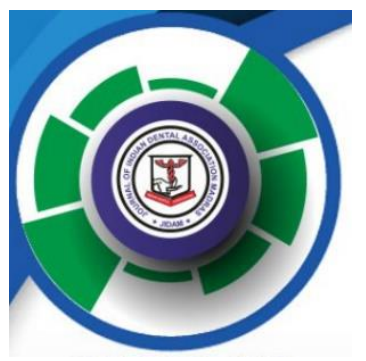

ORIGINAL ARTICLE

\title{
KNOWLEDGE, ATTITUDE AND PRACTICE OF DENTAL IMPLANTS AMONG DENTAL PRACTITIONERS- A REGIONAL SURVEY
}

\author{
Dr. Balaji. V. R, Dr. Manikandan. D, Dr. Soundariya Bala Muralei
}

Department of Periodontology, CSI College of Dental Sciences and Research, Madurai, Tamil Nadu, India.

DOI:10.37841/jidam_2021_V8_I1_03

Address for Correspondence:

Dr.Soundariya Bala Muralei, Postgraduate Student,

Department of Periodontology,

CSI College of Dental Sciences and Research, Madurai,

Tamil Nadu, India.

Email id: sound28perio@gmail.com

Received: 20.02.2021 First Published: 19.03.2021

Accepted: 16.03.2021 Published: 27.03.2021

\section{ABSTRACT}

BACKGROUND: To assess and compare the level of knowledge, awareness and practice of dental implants among dental practitioners in Madurai region through a questionnaire survey.

MATERIALS AND METHODS: A structured questionnaire survey was done to assess the level of knowledge, attitude and practice of dental implants among the dental practitioners through Google form. Two interviewers with dental background did the study, for a period of 4 months. Questions were structured with close-ended and open-ended questions.

RESULTS: 76 participants recorded their responses for this survey. Out of 76 participants, $76.3 \%$ of responders were practicing dental implants. Upon assessing the years of experience, $28 \%$ of responders with 1-3 years of practice were more interested towards implant dentistry. $63.2 \%$ of practitioners had undergone an implant course and the predominant source of knowledge is through books and basic implant course.

CONCLUSION: This survey reflects the current scenario of the practicing dentist, who are updating and upgrading to emerging dental science such as dental implants. Those who had less than 3 years of experience displayed more positive attitude towards dental implants. Majority of dental practitioners despite having good knowledge about dental implants preferred other treatment options due to cost effectiveness of implant therapy.

KEYWORDS: Dental implants, Dental practitioner, Web-based questionnaire and Cross-sectional survey. 


\section{INTRODUCTION}

Implant dentistry has become an excellent modality in replacement of missing teeth as it achieves the goal regardless of the cause of change in the stomatognathic system. ${ }^{1}$ Ground reality of the clinical practice is based on the clinician's knowledge about a treatment and the patient's affordability towards the treatment. With increase in evidence-based dentistry, a dental practitioner's willingness to constantly update his knowledge and attitude towards a treatment modality influences the clinical practice per se. In order to analyze the level of knowledge and practice, a questionnaire-based survey is the basic platform for collection of information from public or professionals. ${ }^{2}$

Hence, the aim of this present study evaluated the level of knowledge and attitude about dental implants, their source of knowledge and other dentist factors such as years of experience, specialization and implant training on the same using a web-based questionnaire.

\section{MATERIALS AND METHODS:}

A web-based cross-sectional survey utilizing a structured questionnaire with multiple-choice questions was conducted among practicing dental professional for a period of four months. The purpose of this study was explained to the participants and consent for the study was obtained. The questions were structured in order to evaluate the level of knowledge concerning dental implants, their source of knowledge and years of clinical experience. Institutional Ethical Committee approval was obtained for this study. (REF: CSICDSR/IEC/0060/2018).

The questionnaire consisted of 2 parts

PART-I- Basic demographic components

PART-II- Questions to elicit the knowledge, level of practice and attitude of dental implants

The questionnaire consisted of both open-ended and closedended questions.

\section{PART I}

Age:

Gender:

Years of Experience:

Qualification:
Locality:

\section{PART II}

1. Are you practicing implants in your clinic?

Yes $\square$ no

2. If yes, how many years you are practicing?
1-3 years
3-6 years

\section{More than 6 years $\square$}

3. If no, why you don't prefer implants?

\section{Expensive $\square$ No awareness among patients $\square$ \\ More inventory $\square \quad$ Other reasons}

4. Do you think whether implants will be the best treatment option for your patients?

Yes $\square \quad$ no

5. What type of implants you are practicing?

\section{Root form implants $\square$ Basal implants}

If others specify

6. Do you do any specialised treatment protocol?

\section{Zygomatic implants $\square$ Pterygoid implants}

\section{All on four implants $\quad \square \quad$ Tilted implants}

If others specify

7. Whether you prefer immediate loading or delayed loading?

\section{Immediate loading $\square$ Delayed loading}

8. If immediate loading why? Or if delayed loading why?

Immediate loading Delayed loading

9. What is the time period for delayed loading in your clinic?

\section{Months $\square \quad 6$ Months $\square \quad$ More than 6 Months $\square$}

10. Whether any failure in implants you have encountered?

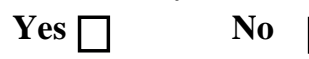

11. If yes, what are the failures you have commonly encountered? 
Positioning error prosthesis error systemic disease surgical error

Occlusal interference If others specify
12. If you do implants with consultants, what type of consultants you prefer?

\section{Periodontist $\square$ Oral surgeon \\ Prosthodontist $\square \quad$ Self}

Others, please specify

13. Do you prefer cantilever in implants?

Yes

no

14. If yes which area do you prefer? Please specify.

15. Have you undergone any implant courses?

Yes no

16. If yes what is the type of course?
Basic course
Training abroad
Advanced course
Others, please specify

17. How would you like to update your knowledge?
Books
Journals
Lectures

\section{CDE program}

YouTube

\section{STATISTICAL ANALYSIS:}

The data were analysed by Statistical Package for Social Sciences (SPSS) version 21. All the data are represented in the form of tables and graphs. Chi-square test was used to assess the level of knowledge, source, and years of experience and practice of dental implants in clinical practice.

\section{RESULTS:}

The results from the present study provides information about the attitude, knowledge, and practice of dental implants among dental practitioners in Madurai region.

A total of 76 responses were obtained in this survey. Demographic data and questionnaire analysis were tabulated in Table- 1 and Table- 2 respectively.
Figure-1 shows the percentage of dental practitioners practicing dental implants in their clinic.

Are you practicing dental implants in your practice?

76 responses

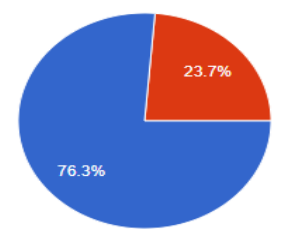

Yes

Figure 1: Percentage of Dental Practitioners practicing

Table-1 shows the demographic data of participants

\begin{tabular}{|c|c|}
\hline $\begin{array}{l}\text { Age (years) } \\
\text { Minimum }=23 \\
\text { Maximum }=55\end{array}$ & $\begin{array}{l}\text { Mean } \pm \text { SD } \\
36.37 \pm 7.187\end{array}$ \\
\hline $\begin{array}{lc}\text { Sex } & \mathrm{n}(\%) \\
\text { Female } & 13(17 \%) \\
\text { Male } & 63(83 \%)\end{array}$ & $\begin{array}{l}X^{2=} 16.74^{a} \\
P \text { value }=0.7\end{array}$ \\
\hline $\begin{array}{l}\text { Years of experience (years) } \\
\text { Minimum }=1 \\
\text { Maximum }=33\end{array}$ & $\begin{array}{l}\text { Mean } \pm \text { SD } \\
36.37 \pm 7.187 \\
X^{2=} 802.909^{a} \\
P \text { value }=<0.05^{*}\end{array}$ \\
\hline $\begin{array}{l}\text { Specialty } \\
\text { BDS } \\
\text { MDS } \\
\text { Periodontist } \\
\text { Prosthodontist } \\
\text { Orthodontist } \\
\text { Endodontist } \\
\text { Pedodontist } \\
\text { Oral pathologist } \\
\text { Oral medicine and } \\
\text { Radiologist } \\
\text { Oral surgeon } \\
\text { MDS with other special } \\
\text { qualification }\end{array}$ & $\begin{array}{l}\text { n }(\%) \\
\mathbf{2 2}(\mathbf{2 9 \%}) \\
\mathbf{5 4}(\mathbf{7 1 \%} \%) \\
17(22.3 \%) \\
5(6.5 \%) \\
7(9.2 \%) \\
6(7.8 \%) \\
3(3.9 \%) \\
3(3.9 \%) \\
5(6.5 \%) \\
7(9.2 \%) \\
3(3.9 \%) \\
X^{2=} 1078.159^{a} \\
P \text { value=0.07 }\end{array}$ \\
\hline
\end{tabular}

Table-1: Demographic data of the participants 
Balaji et al: Knowledge, Attitude and Practice of Dental Implants Among Dental Practitioners

Figure-2 represents the specialist preferred by dental practitioners for placement of dental implants.

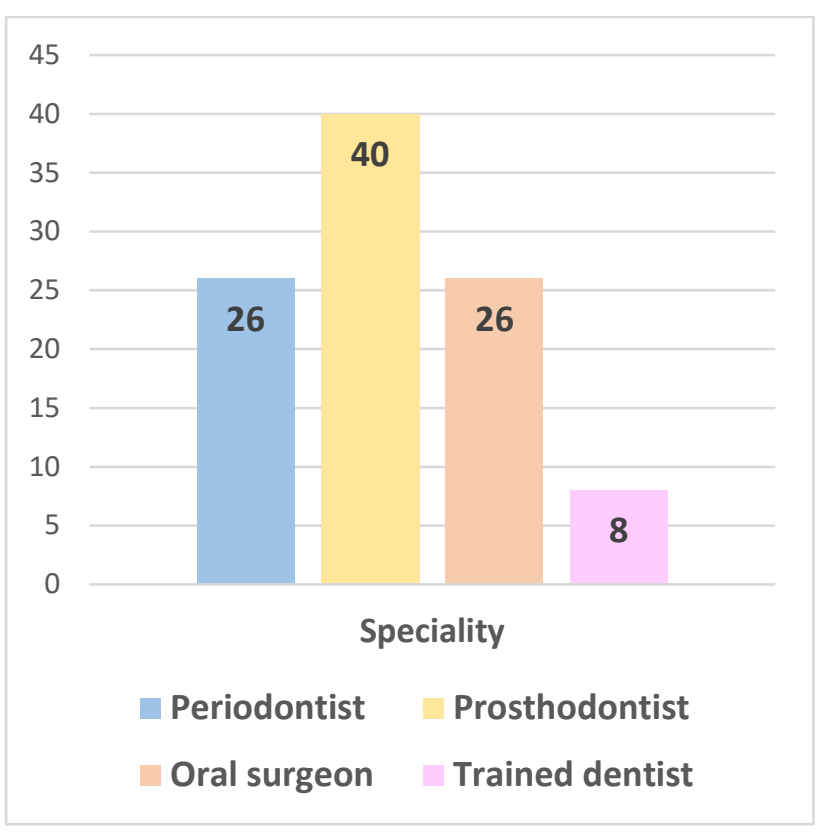

Figure 2: Specialist preferred by practitioners

Figure 3 represents the source of knowledge about dental implants

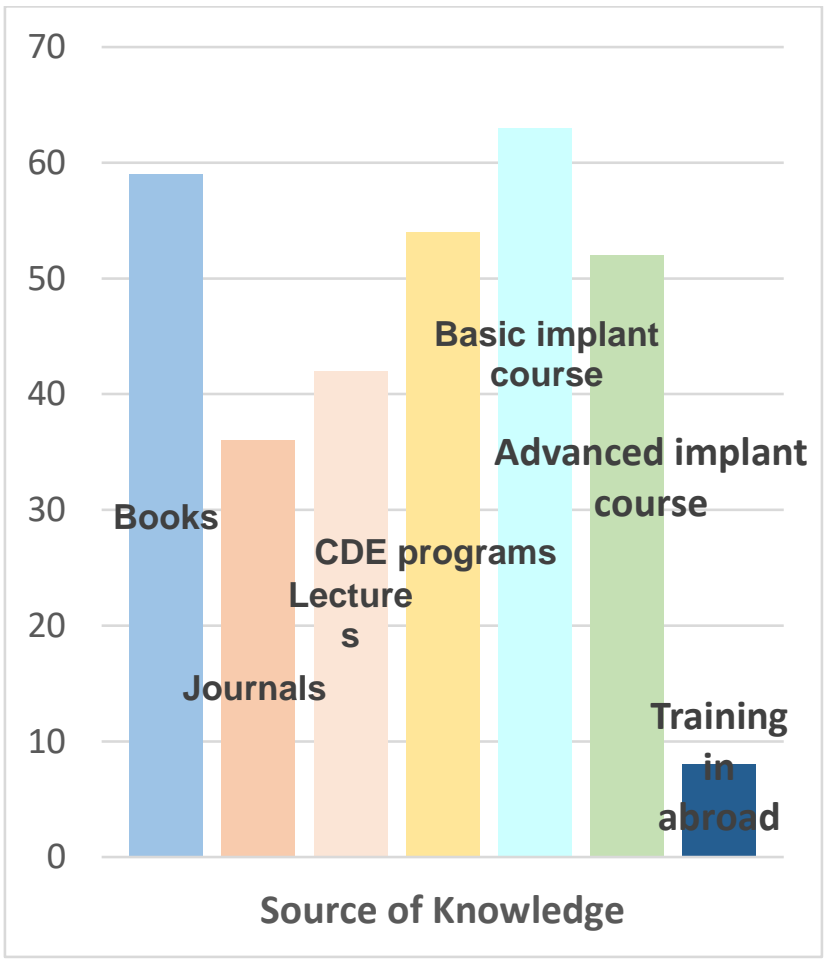

Figure 3: Source of knowledge by practitioners
The following Table 2 shows the Question-wise analysis

\begin{tabular}{|c|c|c|c|}
\hline Question & Responses & $\mathbf{X}^{2}$ & $P$ value \\
\hline $\begin{array}{l}\text { Are you practicing } \\
\text { implants in your } \\
\text { clinic? }\end{array}$ & $\begin{array}{l}\text { Yes }=76.3 \\
\mathrm{No}=23.7\end{array}$ & $17.315^{\mathrm{a}}$ & 0.69 \\
\hline $\begin{array}{l}\text { If yes how many } \\
\text { years you are } \\
\text { practicing? }\end{array}$ & $\begin{array}{c}1-3 \text { years }=28.9 \\
3-6 \text { years }=23.7 \\
\text { More than } 6 \\
\text { years }=23.7\end{array}$ & $82.719^{a}$ & $0.04 *$ \\
\hline $\begin{array}{l}\text { If you practice } \\
\text { implants in your } \\
\text { practice who is } \\
\text { placing implants? }\end{array}$ & $\begin{array}{c}\text { Consultant }=30.3 \\
\text { Myself }=35.5\end{array}$ & $38.588^{a}$ & 0.62 \\
\hline $\begin{array}{l}\text { What type of dental } \\
\text { implants you are } \\
\text { practicing? }\end{array}$ & $\begin{array}{c}\text { Root form }=63.2 \\
\text { Basal }=10.5 \\
\text { Other }=2.6\end{array}$ & $78.629^{a}$ & 0.08 \\
\hline $\begin{array}{l}\text { Do you practice } \\
\text { specialized } \\
\text { treatment protocol } \\
\text { like, [zygomatic } \\
\text { implants] }\end{array}$ & $\begin{array}{l}\text { Yes }=15.8 \\
\mathrm{No}=84.2\end{array}$ & $26.98^{\mathrm{a}}$ & 0.1 \\
\hline $\begin{array}{l}\text { Do you practice } \\
\text { specialized } \\
\text { treatment protocol } \\
\text { like, [tilted } \\
\text { implants, pterygoid } \\
\text { implants] }\end{array}$ & $\begin{array}{l}\text { Yes }=14.5 \\
\mathrm{No}=85.5\end{array}$ & $18.39^{\mathrm{a}}$ & 0.6 \\
\hline $\begin{array}{l}\text { Do you practice } \\
\text { specialized } \\
\text { treatment protocol } \\
\text { like, [all on four] }\end{array}$ & $\begin{array}{l}\text { Yes }=32.9 \\
\mathrm{No}=67.1\end{array}$ & $27.42^{\mathrm{a}}$ & 0.1 \\
\hline $\begin{array}{l}\text { Do you practice } \\
\text { specialized } \\
\text { treatment protocol } \\
\text { like, [all on six] }\end{array}$ & $\begin{array}{l}\text { Yes }=26.3 \\
\mathrm{No}=73.3\end{array}$ & $20.911^{\mathrm{a}}$ & 0.4 \\
\hline $\begin{array}{l}\text { Whether you prefer } \\
\text { immediate loading } \\
\text { or delayed loading? }\end{array}$ & $\begin{array}{c}\text { immediate } \\
\text { loading }=10.5 \\
\text { delayed } \\
\text { loading }=72.5\end{array}$ & $27.29^{\mathrm{a}}$ & 0.9 \\
\hline $\begin{array}{l}\text { Whether any failure } \\
\text { in implants you } \\
\text { have encountered? }\end{array}$ & $\begin{array}{l}\text { Yes }=42.1 \\
\mathrm{No}=36.8\end{array}$ & $44.843^{\mathrm{a}}$ & 0.3 \\
\hline $\begin{array}{l}\text { Do you think } \\
\text { whether implants } \\
\text { will be the best } \\
\text { option for your } \\
\text { patients? }\end{array}$ & $\begin{array}{l}\text { Yes }=69.7 \\
\mathrm{No}=13.2\end{array}$ & $31.584^{\mathrm{a}}$ & 0.87 \\
\hline
\end{tabular}

Volume No: 8, Issue No: 1 


\begin{tabular}{|c|c|c|c|}
\hline $\begin{array}{l}\text { what is the time } \\
\text { period for delayed } \\
\text { loading in your } \\
\text { clinic?( mention for } \\
\text { maxilla and } \\
\text { mandible) }\end{array}$ & $\begin{array}{c}\text { Maxilla : } \\
\text { 1-3 months=2.3 } \\
\text { 3-6 } \\
\text { months=92.4 } \\
\text { More than 6 } \\
\text { months =5.3 } \\
\text { Mandible: } \\
\text { 1-3 } \\
\text { months=75.2 } \\
\text { 3-6 } \\
\text { months }=23.5 \\
\text { More than } 6 \\
\text { months }=1.3\end{array}$ & $566.33^{\mathrm{a}}$ & 1.0 \\
\hline $\begin{array}{l}\text { Have you ever } \\
\text { undergone any } \\
\text { implant course } \\
\text { (basic or } \\
\text { advanced)? }\end{array}$ & $\begin{array}{l}\text { Yes }=63.2 \\
\mathrm{No}=27.6\end{array}$ & $44.494^{\mathrm{a}}$ & 0.3 \\
\hline $\begin{array}{l}\text { Source of your } \\
\text { knowledge? } \\
\text { (Books, Journals, } \\
\text { lectures, CDE } \\
\text { programs) }\end{array}$ & $\begin{array}{l}\mathrm{Yes}=73.3 \\
\mathrm{No}=26.3\end{array}$ & $20.911^{\mathrm{a}}$ & 0.4 \\
\hline
\end{tabular}

Table 2: Questionwise Analysis

Figure 4 represents the reason for not preferring dental implants

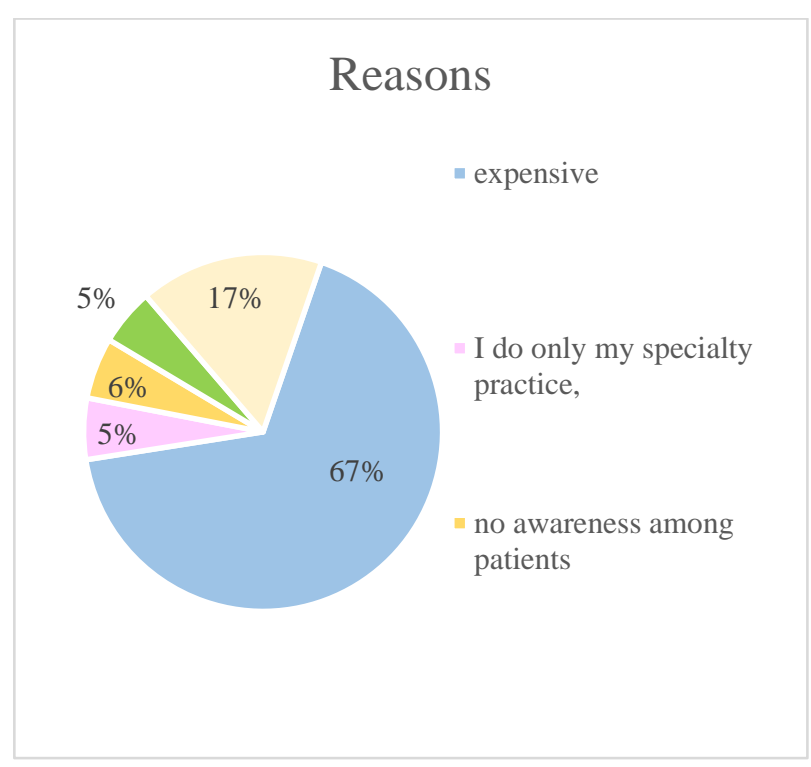

Figure 4: Reason for not preferring dental implants

\section{DISCUSSION:}

Replacement of lost dentition has been a prime factor for an individual to approach a specialist or dentist. A survey conducted by Rasika Manori Jayasinghe et al in 2017 concluded that majority of people $(76.2 \%)$ are aware of different types of teeth replacement options. [3] Dental implant therapy has become a predictable treatment option for edentulous ridges. It has become a day-to-day of every general as well as speciality dental practice. ${ }^{4}$

The results of this survey provides some insight into the daily clinical practice. Factors such as the dentist's years of experience, implant training, and specialization also affect the knowledge, attitude, and practice of dental implants. Dental practitioners with less than 3 years of experience displayed best knowledge, positive attitude, and the most practice for implants. A study conducted by Eckert et al. in 2012 observed that younger Prosthodontists expressed a greater desire to surgically place implants. ${ }^{5}$

Dental practitioners with longer years of experience still prefer conventional methods as a choice for the replacement of missing teeth. Majority of responders $(67 \%)$ reported that cost is the main reason for not preferring dental implants in their practice. Chaudhary et al., 2013 reported in his study that high implant cost and patient's fear for surgery were limiting factor. ${ }^{6}$

Educating ourselves in a newer frontier always increases our attitude and perception towards the concept. Undergoing a training for implant enhances the knowledge, provides a good attitude, and increases the practice of implants. Lang-Hua et al. in 2013 conducted a study to compare the knowledge, attitude towards dental implants among dentist who received implant training and who did not, the results are in accordance with the present survey where dental practitioners with implant training had a superior knowledge and exhibited a positive attitude. ${ }^{7}$

Maalhagh-Fard et al. in 2002 reported that a stronger positive correlation among graduates who have completed implant training as elective. In this survey, Prosthodontist were preferred consultants for placing implants among dental practitioners. This might be due to the concept of prosthetic derived implant placement for better patient related outcomes. However, placement of dental implant is always as a multidisciplinary approach. Dental implant placement is always a team work consisting of a Prosthodontist, Periodontist and Oral Surgeons. Therefore, efforts should be made at the institutional level to extend

Volume No: 8, Issue No: 1 
implants' knowledge, attitude, and practice with other streams as well.

Within the limitation of the study i.e. a small sample size and regional assessment, it can be suggested that budding dental practitioners are more diverse in accepting newer treatment approaches and showed more positive attitude. However, experience in dental practice influences the level of knowledge and practice of dental implants. With better communication between various specialities and with the patient, implementation of dental implants in daily practice is predictable and achievable.

\section{CONCLUSION:}

The knowledge and practice of implants by dental practitioners in this southern region is still limited and there is a need to improve this scenario. Despite, many dental practitioners practicing implant dentistry it is identified that cost and lack of skills are prime factors preventing dentists from practicing implant. One among them is cost effectiveness, hence an effort must be made to educate both the patient and the practicing dentist. The current study shows that there is an increased need for incorporating the basic knowledge and skill related to implant dentistry at the undergraduate level to develop awareness about this branch of dentistry. Though this survey was conducted within a limited group of people, large scale studies are needed to know the level of implant dentistry practiced and various problems encountered in implant dentistry by the dental practitioners in future.

\section{FINANCIAL SUPPORT AND SPONSORSHIP}

Nil

\section{CONFLICTS OF INTEREST}

There are no conflicts of interest.

\section{REFERNCES:}

1. Palmer R. Introduction to dental implants. Br Dent J 1999; 187(3): 127-32.

2. Edwards PJ, Roberts I, Clarke MJet al Methods to increase response to postal and electronic questionnaires. Cochrane Database Syst Rev 2009; 3: MR000008.

3. Jayasinghe, R.M., Perera, J., Jayasinghe, V. et al. Awareness, attitudes, need and demand on replacement of missing teeth among a group of partially dentate patients attending a University Dental Hospital. BMC Res Notes 10, 334 (2017).

4. Varsha Rathod et al.2017, Awareness About Dental Implants Amongst Dental Practitioners in Navi Mumbai: A Knowledge, Attitude And Practice Study. Int J Recent Sci Res. 8(5), pp.17013-17018.

5. Eckert SE, Koka S, Wolfinger G, Choi YG. Survey of implant experience by prosthodontists in the United States. J Prosthodont 2002;11:194-201.

6. Chaudhary, S., Gowda, T., Kumar, T., \& Mehta, D. (2013). Knowledge and attitudes of dental interns in Karnataka state, India, regarding implants. J Dent Educ , 77, 1365-70.

7. Lang-Hua BH, Lang NP, Lo EC, McGrath CP. Attitudes of general dental practitioners towards implant dentistry in an environment with widespread provision of implant therapy. Clin Oral Implants Res 2013; 24: 278-84.

8. Maalhagh-Fard A, Nimmo A, Lepczyk JW, Pink FE. Implant dentistry in predoctoral education: The elective approach. J Prosthodont 2002;11:202-7. 